\title{
PENGEMBANGAN MEDIA PENDIDIKAN UNTUK INOVASI PEMBELAJARAN DI PESANTREN
}

\begin{abstract}
Oleh : The increasingly dynamic development of information technology has implications for Sukandi

Fakultas Syari'ah dan Ekonomi Islam Universitas Ibrahimy Situbondo

Abstract: the world of education, especially learning activities. One of them by using media for helping the easy learning process that is very receive as benefit. Learning media can enhance student learning help to create joyful learning. But is not all learning media that can be applied in every learning environments, because learning media has advantages and disadvantages in several aspect. For the example is classical learning methods such as wetonan and bandongan become a characteristic teaching and learning activities in pesantren. Because of that, require a efforts to develop educational media suitably with the learning and the needs of students. Learning media development procedures iclude are potential and problems, data collection, product design, design validation, revision, small-field trials, revision, large-field trials, revision, massive production.
\end{abstract}

Keywords: development of educational media, learning innovation, pesantren

\section{PENDAHULUAN}

Saat ini manusia di hadapkan pada situasi di mana perkembangan teknologi tidak bisa terbantahkan lagi. Di semua lini kehidupan selalu hadir teknologi. Bahkan jika bisa digambarkan hubungan antara manusia dan teknologi saat ini, kata yang paling tepat adalah sebuah persahabatan. Karena manusia tidak bisa lepas dari teknologi, dan teknologi pun selalu melekat dengan manusia. Tentu dalam parksisnya, teknologi cukup efektif dalam membantu menyelasikan pekerjaan manusia.

Implikasi dari perkembangan teknologi yang semakin pesat ialah seseorang dapat melakukan beberapa pekerjaan dalam waktu bersamaan. Tentu hal ini dapat menekan seminimal mungkin kuantitas waktu yang dibutuhkan dan tenaga yang diperlukan. melalui teknologi, pekerjaan manusia bisa menjadi se-simple mungkin. Bahkan melalui teknologi pula tidak bisa ditemukan lagi yang namanya batasan ruang dan waktu. Semua bergerak dinamis, fleksibel, efektif dan efisien.

Hal tersebut juga dirasakan dalam dunia pendidikan. Di mana siswa dapat melakukan bome work/worksheet yang diberikan guru misalnya, bersamaan dengan aktivitas mencari beragam informasi di internet, mendengarkan musik lewat mobile phone, mengakses sosial media, atau bahkan berkomentar di status orang lain dan sesekali memposting halaman baru di facebook, instagram mereka. Seseorang yang berkesempatan mengalami beragam aktivitas ini dinamakan generasi $Z$. Ada banyak interpretasi tentang generasi $Z$ di kalangan para ahli. Namun mayoritas beberapa pakar menyebut bahwa generasi $\mathrm{Z}$ adalah manusia yang lahir pasca tahun 1996. Karena mereka mempunyai kesempatan akses yang luar biasa, terutama dalam segi teknologi. Sehingga manusia-manusia tersebut dikategorikan ke dalam istilah baru yaitu generasi $\mathrm{Z}$.

Ahli demografi di Amerika Serikat menggunakan istilah generasi $Z$ untuk anak-anak yang lahir di zaman informasi atau post-industrial. ${ }^{1}$ Berlarinya perkembangan pengetahuan dan teknologi informasi yang semakin cepat menjadikan simbol pembelajaran antara murid dan guru mengalami pelompatan yang cukup amaze. Pada sektor pendidikan, tentu anak-

\footnotetext{
${ }^{1}$ Muhammad Wahyuni Nafis, "Model Pendidikan Guru Abad Ke-21". Dalam Redesain Pendidikan Guru; Teori, Kebijakan dan Praktik, ed. Jejen Musfah (Jakarta: Prenadamedia; 2015), 161.
} 
anak generasi $Z$ tidaklah sama dunianya dengan dunia guru yang mengajarnya saat ini. Sebab mayoritas pendidik dewasa ini, lahir pra tahun 1996. Sedangkan muridnya rata-rata lahir jauh pasca tahun 1996. Oleh karena itu pendidik di zaman ini juga perlu menyesuaikan proses belajar mengajar terhadap apa yang dibutuhkan dan disenangi oleh siswa. Sehingga dalam proses belajar mengajar tidak lagi membosankan. Siswa aktif menyerap informasi dan guru aktif dalam memfasilitasi pengetahuan yang dibutuhkan oleh siswa.

Keadaan berbanding terbalik ketika melihat proses pembelajaran di pesantren. Proses pembelajaran di pesantren umumnya berlangsung menggunakan sistem klasikal, seperti sorogan, wetonan dan bendongan. ${ }^{2} \mathrm{Hal}$ ini sangat rentan menimbulkan kesusahan dalam menangkap informasi yang disampaikan oleh guru kepada murid/santri. Mengingat, bahwa hakikat proses belajar mengajar adalah memberikan dan mentransfer informasi dari pengantar ke penerima. ${ }^{3}$

Guna mengefektifkan penyampaian informasi dari pendidik ke peserta didik maka perlu adanya media pembelajaran. Karena penyampaian secara verbatim tidaklah cukup dalam menciptakan suasana pembelajaran yang mudah diserap oleh peserta didik. Apalagi di zaman yang penuh dengan tekhnolgi saat ini, akses dalam menggunakan media pembelajaran tidaklah susah. Akan tetapi dari sekian banyak media pembelajaran yang ada belum tentu tepat guna dalam prakteknya. Harus ada penyesuaian dari seseorang yang akan menggunakan media tersebut. Termasuk penyesuaian dengan metode yang hendak digunakan ataupun penyesuaian dengan karakteristik di sekitar. Sebab itu harus ada banyak informasi yang baik dan benar terkait pengembangan media pendidikan, spesifiknya dalam hal pembelajaran. Diharapkan nantinya setiap pendidik dapat menggunakan media pendidikan yang tepat atas pembelajaran yang hendak dilaksanakan.

\footnotetext{
${ }^{2}$ Ali Maksum, Model Pendidikan Toleransi Di Pesantren Modern Dan Salaf, Jurnal Pendidikan Agama Islam, Vol. 3, No. 1, (Mei, 2015), 87.

3 Ayu Fiska Nurryna, "Pengembangan Media Untuk Inovasi Pembelajaran", Jurnal Sentra Penelitian Engineering dan Edukasi, Vol. 1, No. 2, (Nopember, 2009), 2.
}

\section{PEMBAHASAN}

\section{Pola Pembelajaran di Pesantren}

Sebelum melangkah terlalu jauh tentang bagaimana pola pembelajaran di pesantren, perlu diketahui terlebih dahulu apa arti dari pesantren itu sendiri. Pesantren adalah tempat atau asrama bagi santri belajar mengaji. ${ }^{4}$ Secara tidak langsung pesantren merupakan wahana bagi peserta didik dalam menuntut ilmu agama. Di sana peserta didik sudah terfasilitasi dengan asrama atau kamar sebagai tempat tinggal selama proses menuntut ilmu. Hal ini menandakan bahwa peserta didik yang menuntut ilmu di pesantren haruslah menetap dan tinggal selama berhari-hari, berbulan-bulah, bahkan bertahuntahun sampai memperoleh ilmu yang diinginkannya. Apabila dirujuk dari pengertian di atas, maka ilmu yang diajarkan dalam pesantren identik dengan ilmu-ilmu agama. Namun belum tentu ilmu yang lain tidak diajarkan di pesantren. Tergantung pada tujuan dan karakteristik masing-masing pesantren.

Dalam beberapa hal, pesantren mempunyai korelasi yang sama dengan padepokan. Hal ini karena adanya hubungan historis antara kebudayaan agama Hidu-Budha dan perkembangan Islam di Nusantara. Sebab pertama kali Islam disebarkan di tanah Nusantara, mayoritas masyarakat setempat telah memeluk agama Hindu ataupun Budha. Sehingga dalam beberapa hal antara Islam dan agama HinduBudha terdapat kesamaan. Adapun kesamaan tersebut bukanlah pada sisi syariat, melainkan pada segi bangunan, karakteristik masyarakat, adat-istiadat, kebudayaan, tradisi dan lain-lain. Korelasi persamaan antara pesantren dan padepokan sama-sama memiliki murid, guru, bangunan, dan terdapat proses belajar mengajar. ${ }^{5}$

Meskipun dalam beberapa hal pesantren dan padepokan bisa dikatakan sama, akan tetapi tidak serta-merta bisa dikatakan pula bahwa semua hal yang identik dengan pesantren ialah hasil adopsi dari padepokan. Tentu dari cara pembelajaran dan isi pembelajaran sangat tidak sama. Pesantren menanmkan nilai-nilai Islam dengan mengintegrasikan

\footnotetext{
${ }^{4}$ Tim Pandom Media, Kamus Besar Bahasa Indonesia Edisi Baru (Jakarta: Pandom Media Nusantara, 2014), 656.

${ }^{5}$ Choirul Yusuf dan Suwito NS, Model Pengembangan Ekonomi Pesantren (Purwokerto: STAIN Press, 2009), 28.
} 
adat istiadat masyarakat yang tidak bertentangan dengan hukum syar'i. Para santri yang belajar di pesantren diberi pemahaman tentang agama Islam serta cara beriman kepada Allah SWT dan Baginda Nabi Muhammad SAW.

Cikal bakal pesantren lahir pertama kali dalam asuhan Sunan Ampel di Ampel Denta Surabaya, pada abad Ke-16 M. Berkat bimbingan dan arahan Kanjeng Sunan Ampel, pesantren ini banyak mencetak dai-dai muda yang nantinya mempunyai amanah mensyiarkan agama Islam ke seluruh antero Nusantara. Sehingga melalui dai-dai tersebut banyak pesantren bertebaran sampai pelosok negeri. Hingga sekarang pesantren tetap eksis sebagai sarana pembelajaran agama Islam di Indonesia.

Pesantren juga identik dengan adanya masjid sebagai tempat ibadah para santri dan di lain waktu juga digunakan untuk proses pembelajaran. Biasanya para santri duduk melingkar sesama kelompoknya lalu mendiskusikan hal-hal yang berkaitan dengan syariat agama Islam. Tidak ada ketentuan batasan waktu belajar santri dalam memahami agama Islam yang disepakati oleh sekian banyak pesantren di Indonesia. Mayoritas waktu belajar santri hampir 24 jam sehari. Karena di pesantren, para santri selalu dibiasakan untuk beribadah, mengaji, belajar dan mengurangi waktu tidurnya. Selain itu, asrama sebagai tempat tinggal santri selama menuntut ilmu merupakan sebuah pembeda tersendiri antara pesantren dan lembaga-lembaga pendidikan lain yang berkembang di Indonesia.

Tujuan utama mayoritas pesantren di Indonesia adalah mengajarkan kitab-kitab klasik kepada para santri. ${ }^{6} \mathrm{Hal}$ ini dapat dilihat pada metode yang digunakan di beberapa pesantren. Metode tersebut di antaranya adalah wetonan dan bandongan. Kedua metode ini memiliki karakteristik yang sama, yaitu bertujuan memahamkan kitab kuning atau di lain versi disebut kitab klasik. Metode wetonan adalah metode di mana seorang santri membacakan kitab yang telah dipelajari sebelumnya, kemudian dilantunkan dihadapan kiai atau ustadz. Lain halnya dengan metode wetonan, metode bandongan merupakan metode di mana seorang santri berkumpul

\footnotetext{
${ }^{6}$ Ali Maksum, Model Pendidikan Toleransi Di Pesantren Modern Dan Salaf, Jurnal Pendidikan Agama Islam, Vol. 3, No. 1, (Mei, 2015), 86.
}

di hadapan kiai atau ustadz yang sedang membaca kitab, kemudian para santri tersebut mencatat hal-hal penting yang telah disampaikan oleh kiai atau ustadz tersebut. Meskipun pada kenyataannya beberapa pakar pendidikan berpendapat bahwa metode wetonan dan metode bandongan ini merupakan metode yang dianggap statis dan tradisional. ${ }^{7}$ Lantas juga bukan berarti pesantren tidak mau menerima inovasi dengan diterapkannya kedua metode tersebut, melainkan perlu adanya upaya pengembangan dalam aktivitas pembelajaran sehingga bisa ditemukan inovasi-inovasi terbaharukan dalam lingkungan pesantren.

\section{Media Pendidikan}

Menurut Ki Hajar Dewantara, pendidikan memiliki makna yang begitu luas, yakni sebuah usaha memerdekakan manusia sebagai anggota dari persatuan (rakyat). ${ }^{8}$ Bahkan lebih luas lagi, pendidikan diartikan sebagai hidup. Artinya, pendidikan adalah hidup dan hidup adalah pendidikan. Dalam literatur lain, pendidikan merupakan segala pengalaman belajar yang berlangsung dalam segala lingkungan dan sepanjang hidup. Segala bentuk situasi yang dapat berpengaruh terhadap perkembangan dan petumbuhan manusia dinamakan pendidikan. ${ }^{9}$ Jadi segala situasi yang terjadi dalam bentuk pengalaman belajar dan berlangsung di mana saja, kapan saja, ialah pendidikan. hal tersebut bila ditinjau dari aspek definisi pendidikan secara global.

Mengenai batasan-batasan pendidikan, sejauh ini masih belum ada tokoh-tokoh pendidikan yang meberikan kepastian terhadap batasan definisi pendidikan tersebut. Namun biasanya jika suatu pendidikan pada negara tertentu telah maju, maka dapat dipastikan tingkat kesejahteraan masyarakatnya tinggi. Pendidikan yang maju dapat melahirkan manusia-manusia yang cerdas dan berintelek serta meciptakan sesuatu baru bagi kemanfaatan masyarakatnya. ${ }^{10}$ Lebih eksplisit pendidikan

\footnotetext{
7 Ahmad Shiddiq, "Tradisi Akademik Pesantren", Jurnal Tadris, Vol. 10, No. 2, (Desember, 2015), 3.

${ }^{8}$ Ki Hajar Dewantara, Bagian Kedua Kebudayaan, (Yogyakarta: Majelis Luhur Persatuan Tamansiswa, 2011), 3.

${ }^{9}$ Radja Mudyaharjo, Pengantar Pendidikan; Sebuah Studi Awal Tentang Dasar-Dasar Pendidikan Pada Umumnya Dan Pendidikan di Indonesia (Jakarta, P.T. Raja Grafindo Persada, 2006), 3.

${ }^{10}$ Moh. Nawafil dan Junaidi, "Revitalisasi Paradigma Baru
} 
merupakan suatu proses generasi muda untuk dapat menjalankan kehidupan dan memenuhi tujuan hidupnya secara lebih efektif dan efisien.

Berbicara efektif dan efisien, maka hal ini juga membicarakan sesuatu hal ataupun alat yang tepat guna. Sesuatu hal tersebut bisa berupa media pendidikan. Karena media pendidikan mempunyai posisi yang sangat urgen dalam aktivitas pembelajaran. ${ }^{11}$ Berhasil tidaknya suatu pembelajaran dapat ditinjau dari dua aspek utama, yaitu metode pembelajaran dan media pembelajaran yang digunakan. Pada dasarnya pendidikan yang baik yaitu memang ketika kegiatan pembelajaran bisa berjalan secara efektif dan efisien. Pembelajaran yang aktif dan efisien perlu adanya sebuah kreatifitas dan inovasi, dalam hal ini salah satunya bisa melalui media pembelajaran.

Penting kiranya mengetahui terlebih dahulu tentang apa itu media penmbelajaran. Asal dari kata media yaitu medium sebagai bentuk jamaknya, istilah media berasal dari bahasa latin. ${ }^{12}$ Suatu perantara, penghubung, sarana, ataupun wahana dapat disebut sebagai media. ${ }^{13}$ Sedangkan media pembelajaran adalah sesuatu yang dimanfaatkan sebagai pengantar pesan atau informasi kepada si penerima pesan. Lebih jauh lagi, media pembelajaran didefinisikan sebagai segala sesuatu yang dipergunakan untuk mengantarkan informasi dari sumber informasi ke penerima informasi sehingga terjadi sesuatu yang dapat merangsang pikiran, bertambahnya semangat, perhatian dan kemauan siswa serta berimplikasi pada terjadinya proses pembelajaran dalam diri peserta didik. ${ }^{14}$

Nunuk Suryani menjelaskan bahwa media pembelajaran adalah sebagai wahana guru untuk menyajikan segala sesuatu yang bersifat informasi namun memiliki kelemahan yakni tidak bisa dilihat langsung oleh siswa, akan tetapi dapat disajikan

Dunia Pembelajaran yang Membaskan", Jurnal Pendidikan Islam Indonesia, vol. 4, No. 2, (April, 2020), 216.

${ }^{11}$ Muhamad Ali, "Pengembangan Media Pembelajaran Interaktif Mata Kuliah Medan Elektromagnetik", Jurnal Edukasi Elektro, Vol. 5, No. 1, ( Maret, 2009), 12.

${ }^{12}$ Miarso, Menyemai Benih Teknologi Pendidikan (Jakarta: PUTEKKOM, 2004), 13.

${ }^{13}$ Tim Pandom Media, Kamus Besar Bahasa Indonesia Edisi Baru (Jakarta: Pandom Media Nusantara, 2014), 569.

${ }^{14}$ Suryani dan Agung, Strategi Belajar Mengajar (Yogyakarta: Ombak, 2012), 34. atau digambarkan langsung menggunakan media. ${ }^{15}$ Pekerjaan guru yang pada mulanya sangat menumpuk dan membutuhkan banyak waktu untuk menyampaikan informasi kepada siswa, maka dengan menggunakan media pembelajaran setidaknya waktu dan pekerjaan guru bisa terminimalisir.

Jadi, media pembelajaran adalah suatu perantara yang dapat menyampaikan pesan atau informasi berisikan materi pembelajaran kepada siswa dari seorang pendidik. Sehubungan dengan itu, media pembelajaran juga merupakan sebuah alat bantu yang berfungsi untuk menjelaskan sebagian dari keseluruhan program pembelajaran yang sulit dijelaskan secara verbal. Tentu dalam aktivitas pembelajara, seorang guru tidak mungkin sepenuhnya tidak mendapat kendala dalam menyampaikan materi ajar kepada peserta didik. Berbagai kendala pasti ditemukan, apalagi jika materi yang akan disampaikan tidak bisa disajikan secara verbatim. Maka solusi yang tepat yakni bisa menggunakan media pembelajaran.

Akan tetapi perlu diperhatikan juga bahwa media pembelajaran bukanlah suatu hal yang paling wajib dalam kegiatan belajar. Artinya kegiatan belajar dapat terlaksana meskipun tanpa menggunakan media pembelajaran. Dengan demikian media pembelajaran bisa digunakan sebagai pelengkap atau suplemen saja. Jika tujuan pembelajaran ingin tercapai secara maksimal maka salah satu kuncinya ialah dengan menggunakan media pembelajaran. Nah, pada posisi ini media pembelajaran dapat berperan sebagai alat utama dalam keseluruhan proses pembelajaran. Sepintas bahwa media pembelajaran dapat dijadikan sebagai alat utama, pelengkap, ataupun sebagai suplemen, tergantung siapa yang hendak memakai serta bagaimana kondisi dan kebutuhannya.

Adapun tujuan media pembelajaran sebagai alat bantu dalam aktivitas belajar mengajar adalah sebagai berikut ${ }^{16}$ :

Kegiatan belajar mengajar di kelas bisa terlaksana dengan gampang;

Menjaga kesesuaian antara tujuan belajar dengan materi ajar;

\footnotetext{
${ }^{15}$ Nunuk Suryani, dkk, Media Pembelajaran Inovatif dan Pengembangannya (Bandung: Remaja Rosdakarya, 2018), 3.

${ }^{16}$ Sanaky, Media Pembelajaran Inovatif-Interaktif (Yogyakarta: Kaukaba Dipantara, 2013), 6.
} 
Dalam praktek pembelajaran membantu siswa berkonsentrasi.

Media pembelajaran dapat dijadikan sebagai alat berinteraksi dalam aktivitas belajar mengajar. Interaksi yang positif antara pendidik dan peserta didik dapat meningkatkan daya ingat siswa. Komunikasi yang terbentuk tanpa penggunaan media dengan mengandalkan penggunaan verbatim saja, maka menyebabkan daya ingat peserta didik dalam waktu tiga jam hanya 70\%. Apabila menggunakan media visual tanpa menggunakan komunikasi verbal maka daya ingat peserta didik meningkat menjadi $72 \%$ sedangkan dengan menggunakan keduanya yaitu verbal dan visual maka daya ingat peserta didik dapat meningkat sampai $85 \%{ }^{17}$

Sebab itulah dalam banyak literatur dijelaskan bahwa penggunaan media pembelajaran dapat meningkatkan daya ingat peserta didik karena media dapat menambah perhatian dan motivasi peserta didik terhadap materi pembelajaran. Selain itu penggunaan media pembelajaran dapat membantu siswa berkonsentrasi dalam mengikuti pelaksanaan proses belajar mengajar. Bagi guru, menggunakan media pembelajaran dapat mempermudah penyajian materi saat proses pembelajaran berlangsung.

Fungsi media pembelajaran sebagai alat bantu yang dapat mempengaruhi kondisi dan lingkungan aktivitas belajar mengajar yang telah ditata serta dibentuk oleh guru. Hal lain mengatakan bahwa fungsi media pembelajaran dapat memberikan stimulus terhadap suatu pembelajaran melalui: ${ }^{18}$

Menampilkan hakikat yang nyata;

Menciptakan model lain dari hakikat aslinya;

Membuat konsep abstrak kepada konsep yang lebih konkret;

Menyamakan pendapat;

Mengatasi rintangan waktu, tempat, kuantitas, dan jarak;

Penyajian ulang informasi atau pesan secara

\footnotetext{
${ }^{17}$ Nunuk Suryani, dkk, Media Pembelajaran Inovatif dan Pengembangannya (Bandung: Remaja Rosdakarya, 2018), 9.

${ }^{18}$ Sanaky, Media Pembelajaran Interaktif-Inovatif (Yogyakarta: Kaukaba Dipantara, 2013), 7.
}

konsisten;

Menciptakan lingkungan belajar yang menyenangkan dan menarik sehingga bisa mencapai tujuan pembelajaran secara maksimal.

Selain fungsi, juga terdapat manfaat dari media pembelajaran. Adapun manfaat dari penggunaan media pembelajaran yaitu dapat meminimalisir kesalah pahaman peserta didik terhadap pesan yang telah disampaikan oleh pendidik. Selain itu dapat menghemat waktu persiapan mengajar serta meningkatkan motivasi belajar siswa.

Demikian dapat diurai tentang manfaat media pembelajaran bagi guru dan siswa adalah sebagai berikut.

Manfaat media pembelajaran bagi guru, adalah:

Menolong siswa untuk termotivasi dalam belajar;

Merangsang perhatian siswa agar tertarik terhadap materi ajar yang disampaikan;

Membentuk suasana belajar yang menyenangkan dan tanpa tekanan;

Membangkitkan self-confident guru dalam menerangkan materi.

Manfaat media pembelajaran bagi siswa

Memberi stimulus bagi siswa supaya rajin belajar;

Meningkatkan motivasi siswa untuk belajar di kelas maupun secara mandiri;

Mempermudah siswa menangkap informasi yang disampaikan secara sistemik melalui media pembelajaran;

Memberikan suasan yang joyful-learning sehingga tidak membosankan dan lebih berkonsentrasi pada materi ajar;

Selain itu media pembelajaran bermanfaat sekali sebagai alat yang dapat memperjelas makna bahan pengajaran supaya lebih mudah dipahami oleh siswa, menjadikan metode pembelajaran bermacammacam, membuat siswa banyak terlibat dalam proses 
pembelajaran yang tidak hanya mendengarkan melainkan juga mengamati, presentasi, mengekplorasi, bertanya dan lain sebagainya. ${ }^{19}$

Berharap melalui pemanfaatan penggunaan media pembelajaran dapat menjadi nilai positif tersendiri bagi sekolah. Khususnya bagaimana nantinya sekolah bisa menciptakan peserta didik yang memiliki kompetensi sebagai lulusan yang handal. $\mathrm{Nah}$, dalam menggunakan media pembelajaran yang baik dan benar, tentu terdapat prinsip-prinsip yang harus diperhatikan. Di antara prinsip-prinsip tersebut adalah sebagai berikut:

Menggunakan media pembelajaran seyogiayanya dapat dikombinasikan dengan seluruh kompenen dalam aktivitas belajar mengajar.

Seseorang yang menggunakan media pembelajaran hendaknya menguasai teknik-teknik media yang digunakan.

Guru seharusnya mengestimasi untung ruginya pemanfaatan suatu media pembelajaran.

Menggunakan media pembelajaran harus dipakai secara terorganisir dan sistemik, bukan sembarang menggunakannya.

Sekiranya materi pembelajaran membutuhkan lebih dari satu macam media, guru dapat memanfaatkan multimedia yang menguntungkan dan memperlancar proses belajar mengajar serta dapat memberikan stimulus bagi siswa untuk selalu belajar.

Selanjutnya media pembelajaran terdiri dari beberapa jenis, di antaranya adalah media berbasis manusia, media berbasis cetakan seperti buku, media visual seperti mapping, media audio-visual seperti televisi, dan media komputer. Namun jika dilihat dari segi teknologi, media dapat terbagi menjadi dua golongan, yaitu media klasik dan media teknologi modern. Media klasik seperti handout, slides, proyeksi dan lainya. Sedangkan media teknologi modern seperti zoom, webinar, telekonferensi dan lain-lain. jamaAdapun rincian dari media tradisional dan media mutakhir sebagaimana berikut:

Dengan mengetahui jenis-jenis media

\footnotetext{
${ }^{19}$ Nunuk Suryani, dkk, Media Pembelajaran Inovatif dan Pengembangannya (Bandung; Remaja Rosdakarya, 2018), 14.
}

pembelajaran maka dapat dimanfaatkan oleh guru dalam menentukan dan memilih media yang sesuai. dengan demikian seorang guru dapat mengembangkan media pembelajaran yang dibutuhkan pada pelaksanaan proses pembelajaran dan disenangi oleh peserta didik.

\section{Pentingnya Pengembangan Media Pembelajaran}

Pada saat menyusun kurikulum, silabus dan rencana pelaksanaan pembelajaran yang akan diimplementasikan dalam proses pembelajaran, tentunya guru telah mempertimbangkan segala aspek yang diperlukan guna menciptakan pembelajaran yang baik bagi siswa. Merupakan dambaan bagi setiap guru bilamana materi ajar yang disampaikan cepat dimengerti oleh peserta didik. Sebab itu setiap guru pasti berusaha mengemas materi ajarnya sebagus mungkin agar peserta didik dapat memahami pelajaran tersebut. Bahkan tidak sedikit para guru yang membahasakan materi ajar dengan bahasa sehari-hari atau dengan kata lain membahasakan sesederhana mungkin agar pesan yang disampaikan dapat dicerna oleh peserta didik.

Agar lebih efektif penyampaian materi pembelajaran kepada siswa serta kemudahan dalam menerima materi tersebut, maka diperlukan alat bantu pendidikan yang disebut media pembelajaran. Seyogianya guru harus bisa menggunakan media pembelajaran yang tepat dalam proses pembelajaran. Namun dalam menentukan kadar ketepatan media pembelajaran yang cocok bagi peserta didik pada aktivitas belajar tertentu, dibutuhkan sebuah upaya pengembangan media pembelajaran. Aktivitas pengembangan media pembelajaran merupakan aktivitas yang terintegrasi dengan penyusunan kurikulum, silabus, dan RPP. Sebab itulah bukan hanya kurikulum, silabus dan RPP yang perlu dikembangkan melainkan juga media pembelajaran. ${ }^{20}$ Karena media pembelajaran sama pentingnya dalam memudahkan peserta didik menangkap materi ajar yang disampaikan.

Melihat kondisi geografis Indonesia yang terbentang ribuan pulau dengan lautan yang mengitarinya, tentu menjadi sebuah kendala tersendiri bagi pemerintah dalam mendistribusikan segala hal

\footnotetext{
${ }^{20}$ Rayandra Asyhar, Kreatif Mengembangkan Media Pembelajaran (Jakarta: Gaung Persada, 2011), 27.
} 
yang diperlukan oleh seluruh sekolah. Termasuk sarana dan prasarana sekolah, bahan ajar, dan media pembelajaran. Perkembangan sekolah sangat memungkinkan tidak merata akibat kendala tersebut. Apalagi di pesantren yang notabenenya sebagian besar pembiayaan menggunakan swadaya pribadi dan masyarakat. Sebab pesantren merupakan sebuah lembaga yang independen pula nyentrik. Tentulah banyak terdapat keterbatasan dalam pesantren, khususnya pada segi proses belajar mengajar.

Berdasarkan paparan tersebut, maka perlu dikembangkan media pembelajaran yang sesuai dengan kebutuhan santri dan guru yang mengajar. Dengan demikian keterbatasan tersebut bukan lagi menjadi sebuah kendala yang krusial dalam menciptakan proses pembelajaran yang kreatif dan inovatif. Sebab pada praksisnya masih banyak ditemukan beberapa guru yang cenderung menyampaikan materi ajar kepada peserta didik dengan menggunakan metode ceramah. Hadirnya media pembelajaran dan upaya mengembangkannya diharapkan dapat mengentaskan persoalan tersebut. Semua guru dan siswa berhak untuk megeksplorasi pembelajarannya sesuai dengan target, tujuan, dan kebutuhan.

Masing-masing media pembelajaran tentu mempunyai plus-minus dalam penggunaan. Contoh sederhana ialah media cetak, dari sisi pembiayaan tentu media cetak dapat menghabiskan biaya yang cukup besar. Di sisi lain media cetak adalah media yang gampang digunakan dan mudah dikembangkan. Media elektronik juga bisa digunakan sebagai media pembelajaran yang menyenangkan bagi siswa, akan tetapi di satu sisi perlu bantuan teknologi komputer dalam mengoperasikan alat tersebut. Hal ini adalah plus-minus dari media pembelajaran, dengan demikian melalui aktivitas pengembangan media pembelajaran memungkinkan menciptakan alternatif solusi dan pemecahan masalah.

Dalam mengembangkan media pembelajaran dibutuhkan kompetensi dari seorang guru. ${ }^{21}$ Setidaknya guru bisa menganalisis segala hal yang dibutuhkan pada saat proses pembelajaran. Ketika kebutuhan-kebutuhan dalam proses pembelajaran

\footnotetext{
${ }^{21}$ Nunuk Suryani, dkk, Media Pembelajaran Inovatif dan Pengembangannya (Bandung: Remaja Rosdakarya, 2018), 123.
}

sudah ditemukan, maka langkah selanjutnya adalah menentukan alternatif media pembelajaran yang tepat guna. Di lain sisi guru juga harus mampu dalam memanfaatkan teknologi informasi dan komunikasi untuk kepentingan belajar mengajar, sebagaimana yang tertuang dalam Peraturan Menteri Pendidikan Nasional Nomor 16 Tahun 2007 tentang Standar Kualifikasi Akademik dan Kompetensi Guru.

Kegiatan pembelajaran yang aktif dan menyenangkan salah satu caranya dapat dicapai dengan menggunakan media pembelajaran. Melalui media, aktivitas belajar mengajar bisa menjadi lebih joyful learning. Siswa dapat menangkap pesan melalui berbagai bentuk variasi dan tidak hanya berbentuk verbatim saja. Apabila media pembelajaran yang digunakan telah sesuai dengan apa yang diinginkan siswa dan apa yang dibutuhkan guru pada saat kegiatan belajar mengajar berlangsung, maka diharapkan hal tersebut bisa meningkatkan efektifitas pembelajaran yang berakhir pada meningkatnya hasil belajar siswa.

Kekurangan dan keterbatasan persediaan media pembelajaran yang ada dapat teratasi dengan upaya pengembangan media pembelajaran. Dengan kata lain, sebuah pengembangan media pembelajaran berfungsi untuk mengatasi kekurangan dan keterbatasan penyediaan media pembelajaran dalam proses belajar mengajar. Di samping itu, hasil pengembangan media pembelajaran yang dilakukan oleh guru bisa menepis ketidaktepatan dan ketidaksesuaian pemilihan media. Melalui pengembangan media pembelajaran, seorang guru dapat bertambah wawasannya serta memperkaya opsi media yang dapat dijadikan acuan atau pedoman dalam mengatasi kesulitan belajar dan mendukung keefektifan belajar.

\section{Langkah-Langkah Pengembangan Media}

Terdapat beberapa cara dalam mengembangkan produk pendidikan. Dalam hal ini yang dimaksud produk pendidikan adalah media pembelajaran. Salah satu cara tersebut ialah dengan menggunakan tekhnik Borg and Gall. Sebelum menjelaskan apa dan bagaimana tekhnik Borg and Gall, terlebih dahulu perlu diurai tentang pengertian pengembangan.

Menurut Borg and Gall, pengembangan adalah sebuah usaha menilai dan memberikan 
alternatif-alternatif terbaharukan terhadap produk pendidikan. Segala sesuatu yang bersifat cara atau proses mengembangkan, maka hal tersebut dikatakan sebagai pengembangan. bahasa lain, pengembangan adalah sebuah upaya memproduksi sesuatu yang baru dan terus menerus berupaya menghasilkan opsi-opsi terbaharukan. ${ }^{22}$

Dalam buku yang ditulis oleh Sugiyono dijelaskan bahwa model tersebut terdiri dari 10 langkah. 10 langkah tersebut di antaranya ialah potensi dan masalah, pengumpulan data, desain produk, validasi desain, revisi desain, uji coba produk, revisi produk, uji coba pemakaian, revisi produk, produksi masal. Supaya lebih jelas tentang beberapa metode tersebut, akan dijelaskan sebagaimana berikut. ${ }^{23}$

Potensi dan masalah

Potensi adalah sesuatu yang apabila didayagunakan memiliki nilai tambah tersendiri. Sedangkan masalah adalah sesuatu yang menyimpang antara yang seharusnya dan yang terjadi di lapangan (fakta). Pada tahap ini segala hal yang berkaitan dengan kebutuhan peserta didik haruslah menjadi catatan penting. Sebab dari kebutuhan peserta didik tersebut nantinya ditemukan sebuah potensi penelitian yang akan dijadikan dasar sebagai pengembangan media pembelajaran. Pengembangan media pembelajaran yang baik adalah sebuah upaya pengembangan yang berlandaskan pada kebutuhan di lapangan. Sesuatu yang tidak terlalu dibutuhkan di lapangan, maka sebaiknya tidak menjadi prioritas dalam upaya pengembangan produk. Pengembangan produk juga bisa berangkat dari sebuah permasalahan yang ada. Dengan adanya masalah tersebut, diharapkan dapat memberikan solusi yang tepat dari sebuah upaya pengembangan produk pembelajaran.

Pengumpulan data

Setelah menemukan potensi ataupun masalah, maka langkah selanjutnya adalah proses pengumpulan data. Adapun aktivitas pengumpulan data ini bertujuan untuk memperoleh segala informasi atau pesan yang nantinya dibutuhkan

\footnotetext{
${ }^{22}$ Hendayat Sutopo dan Westy Soemanto, Pembinaan dan Pengembangan Kurikulum Sebagai Substansi Problem Administrasi Pendidikan (Jakarta: Bumi Aksara, 1993), 45.

${ }^{23}$ Sugiyono, Metode Penelitian Pendidikan: Pendekatan Kuantitatif, Kualitatif, dan R\&D (Bandung: Alfabeta, 2017), 9.
}

dalam pengembangan media pembelajaran. Informasi yang biasanya dibutuhkan adalah tentang bagaimana prosedur pengembangan yang baik dan benar, apa saja kompetensi inti dan kompetensi dasar yang akan dikembangkan dalam media pembelajaran atau bahan ajar tertentu. Selain itu, dibutuhkan juga tentang informasi-informasi tambahan berkaitan dengan produk yang akan dikembangkan.

Pengumpulan data dapat dilakukan dengan dua cara, yaitu studi literatur dan studi lapangan. Studi literatur adalah kegiatan memperolah informasi dengan menelaah sumber-sumber pustaka, seperti buku, koran, majalah, jurnal dan lain sebagainya. Studi lapangan adalah kegiatan memperoleh informasi yang dihasilkan langsung dari proses pengamatan lapangan. informasi-informasi yang diperoleh dari studi lapangan dan studi pustaka ini selanjutnya dijadikan bahan dalam merancang desai produk yang hendak dikembangkan.

\section{Desain produk}

Setelah memperoleh informasi dari kedua tahap di atas, maka selanjutnya ialah membuat rancangan produk. Pada tahap ini produk yang akan telah dikembangkan berdasar pada potensi dan masalah serta data-data yang diperoleh mulai dibentuk sesuai kebutuhan. Produk yang dibuat masih bersifat kerangka, sebab rancangan produk akan diuji oleh beberapa validator di tahap selanjutnya.

Validasi desain

Rancangan atau desain produk yang telah jadi selanjutnya dinilai oleh validator pada tahap ini. Validator yang dibutuhkan setidaknya terdiri dari validator ahli materi dan validator ahli media. Validator ahli materi adalah seseorang yang kompeten di bidangnya untuk memberikan nilai dari aspek materi/ isi pada desain yang telah dirancang. Sedangkan ahli media adalah seseorang yang kompeten di bidangnya untuk memberikan nilai dari aspek dimensi/bentuk pada desain yang telah dirancang.

Revisi desain

Selanjutnya, hasil nilai yang diperoleh dari ahli materi dan ahli media dijadikan bahan untuk penyempurnaan produk. Kritik dan saran yang diberikan oleh para ahli terhadap produk yang telah 
dikembangkan harus segera diperbaiki sebelum melangkah ke tahap selanjutnya. Apabila produk telah direvisi, maka produk siap untuk diuji cobakan pada tahap uji coba produk.

Uji coba produk

Tahap ini merupakan tahap di mana produk akan diterapkan pada peserta didik. Di sini pula produk yang telah dibuat bisa dirasakan oleh peserta didik secara langsung. Uji coba produk membutuhkan responden minimal berjumlah 7 orang. Siswa yang berperan sebagai responden dalam uji coba ini akan diberi angket atau pertanyaan wawancara terkait respon dari penggunaan produk yang telah dikembangkan.

\section{Revisi produk}

Masukan-masukan yang diperoleh dari kelas kecil harus diperbaiki pada tahap revisi produk. Pada tahap ini produk direvisi sesuai dengan komentar responden pada tahap uji coba produk. Jika komentar para responden mengatakan bagus, artinya tidak ada yang perlu direvisi terkait produk yang telah dikembagkan, maka produk bisa langsung diuji cobakan pada tahap uji coba pemakaian.

Uji coba pemakaian

Uji coba pada tahap ini kerap kali disebut juga sebagai uji coba skala besar atau uji coba kelas besar. Karena produk yang telah melewati beberapa tahap sebelumnya akan diuji coba dalam skala besar dan membutuhkan responden yang juga besar. Instrumen pada tahap uji coba skala besar bisa menggunakan soal-soal atau angket, tergantung pada jenis produk yang dikembangkan. Di tahap uji coba pemakaian membutuhkan waktu dan biaya yang cukup besar sehingga peneliti atau perancang produk harus benar-benar memperhatikan segala hal yang dibutuhkan.

Revisi produk

Jika ada masukan atau saran yang perlu disempurnakam dari hasil data yang diperoleh pada tahap uji coba pemakaian, maka produk harus tetap direvisi sampai mendekati titik ideal. Apabila produk sudah sesuai dan berhasil pada tahap uji coba skala besar, maka produk siap diproduksi secara masal.
Produksi masal

Tahap ini adalah tahap di mana produk sudah ideal, dan telah berhasil melewati beberapa tahap di atas. Setelah itu, produk siap diproduksi secara masal.

Prosedur pengembangan pada produk pembelajaran, yakni dalam hal ini juga merupakan media pembelajaran, terdapat 10 langkah yaitu potensi dan masalah, pengumpulan data, desain produk, validasi desain, revisi desain, uji coba kelas kecil, revisi produk, uji coba pemakaian kelas besar, revisi produk, terakhir produksi masal. Setelah mengetahui prosedur pengembangan bahan ajar, diharapkan pendidik bisa mengembangkan media pembelajaran yang sesuai dan benar.

\section{SIMPULAN}

Tidak ada batasan waktu belajar di pesantren, sebab waktu belajar santri hampir 24 jam sehari. Santri memang ditempa untuk banyak beribadah, belajar, ngaji dan mengurangi tidur. Metode pembelajaran yang diterapkan di pesantren secara umum ada dua, yaitu metode wetonan dan metode bandongan. Beberapa pakar berpendapat bahwa metode ini terlalu statis dan tradisional sehingga perlu adanya pengembangan dalam bentuk media pendidikan guna menemukan inovasi-inovasi pembelajaran di pesantren. Secara istilah, metode pembelajaran adalah perantara atau wahana yang digunakan oleh pendidik untuk mengantarkan informasiinformasi yang berisikan materi ajar kepada peserta didik. Sederhananya, media pembelajaran juga dapat diartikan sebagai cara berkomunikasi dalam menghantarkan pesan dari pendidik kepada peserta didik. Media pembelajaran sangat penting dikembangkan sebab luasnya kondisi geografis Indonesia yang sangat memungkinkan berakibat pada keterbatasan media pendidikan di sekolahsekolah, dalam hal ini juga pesantren sebagai institusi pendidikan Islam yang pendanaannya mayoritas bersumber dari swadaya pribadi dan masyarakat. Di samping itu, melalui upaya pengembangan media pembelajaran dapat memberi stimulus pada diri siswa untuk semangat belajar dan menciptakan suasana belajar yang joyful learning. Terdapat beberapa prosedur dalam mengembangkan media pembelajaran atau produk pendidikan, menurut Borg and Gall terdapat 
10 tahap pengembangan, di antaranya yaitu potensi dan masalah, pengumpulan data, desain produk, validasi desain, revisi desain, uji coba kelas kecil, revisi produk, uji coba pemakaian kelas besar, revisi produk, terakhir produksi masal. Setelah mengetahui prosedur pengembangan bahan ajar, diharapkan pendidik bisa mengembangkan media pembelajaran yang sesuai dan benar.

\section{DAFTAR PUSTAKA}

Ali, Muhamad. "Pengembangan Media Pembelajaran Interaktif Mata Kuliah Medan Elektromagnetik", Jurnal Edukasi Elektro, Vol. 5, No. 1, (Maret, 2009)

Asyhar, Rayandra. Kreatif Mengembangkan Media Pembelajaran. Jakarta: Gaung Persada, 2011.

Dewantara, Ki Hajar. Bagian Kedua Kebudayaan. Yogyakarta: Majelis Luhur Persatuan Tamansiswa, 2011.

Maksum, Ali. Model Pendidikan Toleransi Di Pesantren Modern Dan Salaf, Jurnal Pendidikan Agama Islam, Vol. 3, No. 1, (Mei, 2015)

Miarso. Menyemai Benih Teknologi Pendidikan. Jakarta: PUTEKKOM, 2004.

Mudyaharjo, Radja. Pengantar Pendidikan; Sebuah Studi Awal Tentang Dasar-Dasar Pendidikan Pada Umumnya Dan Pendidikan di Indonesia. Jakarta, P.T. Raja Grafindo Persada, 2006.

Nafis, Muhammad Wahyuni. "Model Pendidikan Guru Abad Ke-21". Dalam Redesain Pendidikan Guru; Teori, Kebijakan dan Praktik, ed. Jejen Musfah. Jakarta: Prenadamedia; 2015.

Nawafil, Moh. dan Junaidi. "Revitalisasi Paradigma Baru Dunia Pembelajaran yang Membaskan", Jurnal Pendidikan Islam Indonesia, vol. 4, No. 2, (April, 2020)

Nurryna, Ayu Fiska. "Pengembangan Media Untuk Inovasi Pembelajaran”, Jurnal Sentra Penelitian Engineering dan Edukasi, Vol. 1, No. 2, (Nopember, 2009)

Sanaky. Media Pembelajaran Inovatif-Interaktif. Yogyakarta: Kaukaba Dipantara, 2013.
Shiddiq, Ahmad. "Tradisi Akademik Pesantren", Jurnal Tadris, Vol. 10, No. 2, (Desember, 2015)

Sugiyono. Metode Penelitian Pendidikan: Pendekatan Kuantitatif, Kualitatif, dan R\&D. Bandung: Alfabeta, 2017.

Suryani dan Agung. Strategi BelajarMengajar. Yogyakarta: Ombak, 2012.

Suryani, Nunuk. Dkk. Media Pembelajaran Inovatif dan Pengembangannya. Bandung: Remaja Rosdakarya, 2018.

Sutopo, Hendayat dan Westy Soemanto. Pembinaan dan Pengembangan Kurikulum Sebagai Substansi Problem Administrasi Pendidikan. Jakarta: Bumi Aksara, 1993.

Tim Pandom Media. Kamus Besar Bahasa Indonesia Edisi Baru. Jakarta: Pandom Media Nusantara, 2014.

Yusuf, Choirul dan Suwito NS. Model Pengembangan Ekonomi Pesantren. Purwokerto: STAIN Press, 2009. 